\title{
Analytical evaluation of technical and operational indicators impact on the transportation technology by automobile trailers
}

\section{Oleh Tson}

Ternopil Ivan Pul'uj National Technical University, 56 Ruska str., 46001 Ternopil, Ukraine

PhD, Assistant Professor, Department of Transport Technology

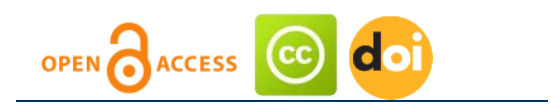

Article history:

Received: October, 2016

1st Revision: October, 2016

Accepted: November, 2016

\section{DOI:}

10.14254/jsdtl.2016.1-1.4

\begin{abstract}
The impact of technological and operational indicators on the efficiency of using operational time during goods transportation by automobile trailers is analytically studied. The failure cause of automobile trailers undercarriages is analysed. The analytical dependences for the preliminary assessment of metal undercarriages performance in the design phases are developed. The proposed mathematical standard vehicle-performance test is compared with the obtained experimental data.
\end{abstract}

Keywords: transportation technology, automobile trailer, technical indicators, operational indicators.

\section{Introduction}

The reduction of time for maintenance and repair of trailers improves the economic performance of their use. The automobile trailer undercarriage components frequently get out of order due to the poor state of roads and improper use of trailers (significant overload, uneven distribution of goods, the level of aggressiveness of materials transported) (fig.1).

The constructions of frames constitute a significant part of machines and influence their performance. Typically, frames are manufactured by welding component units made of carbon steel. In the frames of automobile trailers, welded joints are the least durable items (Popovych, \& Rybak, 2010). The failure cause is found to be a sharp drop in stiffness when moving from one unit to another; a large cluster of welds; their placement in areas of high stress under the action of operating loads; defects in welds. The estimation of vehicles welded frames is based on traditional calculations of strength by the allowable stresses.

The main types of units in welded frames are the connections of structural sections arranged in various combinations. It is characteristic that the length of welds is short enough and that the welds are located in different directions (Table. 1) (Popovych, \& Rybak, 2010; Rybak, 2003). 


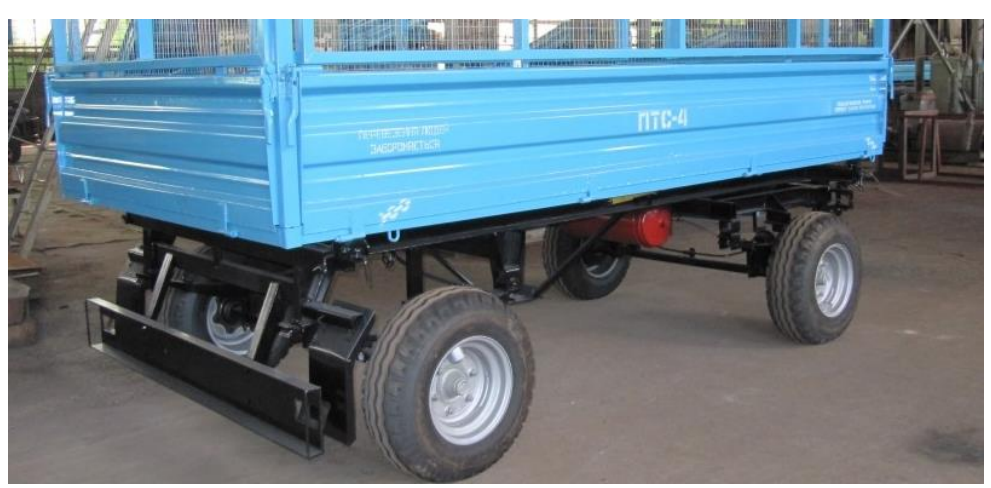

Fig. 1. Automobile trailer 2PTS-4

\begin{tabular}{|c|c|c|c|c|c|c|c|}
\hline \multirow{3}{*}{$\begin{array}{l}\text { Denomination, } \\
\text { car make }\end{array}$} & \multirow[b]{3}{*}{ Mass, kg } & \multicolumn{5}{|c|}{ Frame structures } & \multirow{3}{*}{$\begin{array}{c}\text { Relative } \\
\text { density of } \\
\text { welded metal, } \\
\mathrm{kg} / \mathrm{g}\end{array}$} \\
\hline & & \multirow[b]{2}{*}{$\begin{array}{c}\text { Mass, } \\
\text { kg }\end{array}$} & \multirow[b]{2}{*}{$\begin{array}{l}\% \text { mass of } \\
\text { machine }\end{array}$} & \multirow{2}{*}{$\begin{array}{c}\text { Type of } \\
\text { section. } \\
\text { Cross- } \\
\text { section, mm }\end{array}$} & \multicolumn{2}{|c|}{ Welds length, run. mm } & \\
\hline & & & & & total & $\begin{array}{l}\text { single } \\
\text { weld }\end{array}$ & \\
\hline $\begin{array}{l}\text { Trailer } \\
\text { 2PTS-4 (887A) }\end{array}$ & 1520 & 273 & 15.3 & $\begin{array}{c}\text { Channel, } \\
17 \times 70 \times 6 \\
120 \times 60 \times 6 \\
100 \times 50 \times 5 \\
\text { List } 5.6\end{array}$ & 8.8 & 1.460 & 14.3 \\
\hline
\end{tabular}

\section{Main material}

The process of accumulating irreversible fatigue damages defines the performance of metal undercarriage exposed by the action of random excitation during the operation. Failure is the result of the main cracks. The standard failure cause of metal structures is multi-cycle fatigue, which occurs when stresses do not exceed macroscopic elastic limit. According to the recent researches, the relationship between stress and deformation of the metal is nonlinear at sufficiently small amplitudes (close to fatigue limit) of variable load. The following phenomena are observed: a closed loop of mechanical hysteresis; the strain force applied to loading the structure element; stronger force of strain applied to unloading the structure element; defined by hysteresis loop a part of energy, which dissipates in the metal for irreversible processes. Thus, at low stresses, the area of hysteresis loop does not dependent on the amplitude of alternative loading but on the speed of loading.

The constituent part of designing welded frames is the calculation of their strength and durability. To perform such calculation, it is necessary to research stamina of the most loaded welded units. In order to reduce the time spent on analytical and experimental evaluation, minimization of used funds, and cost reduction of the product, it is necessary to consult reference books that contain the performance indicators of structural and technological options of units that possess much rational indicators as compared with other options (Popovych, \& Rybak, 2010; Dmytrychenko, 2003).

To design new trailers and develop frame construction welds, the units should be classified by the structural forms and types of load, the rational options of standard units should be tested, and the structural sections should be standardized. Typically, in the design phase, the assessment of undercarriages is based on calculations of the performance of the most loaded welded units for assessing the strength and durability of the structure as a whole.

For this reason, in the design phase, without the results of strain measurement of manufactured structures, the adequate mathematical model predicting the structure performance should be applied (Dmytrychenko, 2006).

The modification of the linear hypothesis of summing the accumulated damages caused by fatigue is often applied to metal structures. In particular, fatigue damage caused by the stress amplitude is a part of the total damage, which corresponds to the appearance of a fatigue crack; or damage caused by the cycle of stress does not dependent on the details now and on the previous load, but is summed up with the damage caused by the previous cycles. The value of variable stresses and the number of change cycles, which the metal structure can withstand before destruction, are linked by Wohler curve (Chernovol, Hrankin, Malakhov, \& Cherkun, 1998)

$$
\sigma^{m} \cdot N=\sigma_{R}^{m} \cdot N_{0}
$$


or

$$
N=N_{0} \cdot\left(\frac{\sigma_{R}}{\sigma}\right)^{m}
$$

Where m-exponent depends on the material, type of load, stress concentration, and asymmetry factor. It characterizes the slope of the left part of the curve to the abscissa axis, and equals the cotangent of the angle $\alpha$, the slope of the left part of the curve of fatigue.

The resulting relationship for performance estimation according to [3]

$$
T=a / D
$$

where $a$-dimensionless value of accumulated damage to the stage of the ultimate state;

$$
D=n \cdot \int_{\sigma_{\min }}^{\sigma_{\max }} \frac{f(\sigma)}{N(\sigma)} d \sigma
$$

$D$ - accumulated damage per unit of time;

$n$ - the expected number of cycles per unit of time;

$f(\sigma)$ - the density of distribution of stress amplitudes;

$N(\sigma)$ - fatigue curve equation (2).

To calculate $\mathrm{T}$ performance in the design phase with $a=1$, equation parameters of metal structure fatigue curve are applied - analogue (2).

In mechanical engineering, in the case of multi-cycle fatigue, the satisfactory agreement with the empirical distributions is provided by Weibull - Gnedenko distribution (Rybak, 2003; Dmytrychenko, 2003; Chernovol, et all, 1998).

$$
f(\sigma)=\frac{b}{a} \cdot\left(\frac{\sigma}{a}\right)^{(b-1)} \cdot e^{-\left(\frac{\sigma}{a}\right)^{b}}
$$

where $\mathrm{b}=\frac{1}{\mathrm{~V}^{1.069}}$ - distribution parameter;

$V$ - coefficient of variation, $V=0.3-0.4$;

$a=\frac{E}{\left(0.55 \cdot V^{2}-0.57 \cdot V+1.02\right)}-$ distribution parameter;

$E$ - mathematical expectation (based on statistics).

Therefore, for the preliminary assessment of the performance of trailer undercarriages in the design phase, the dependences are applied

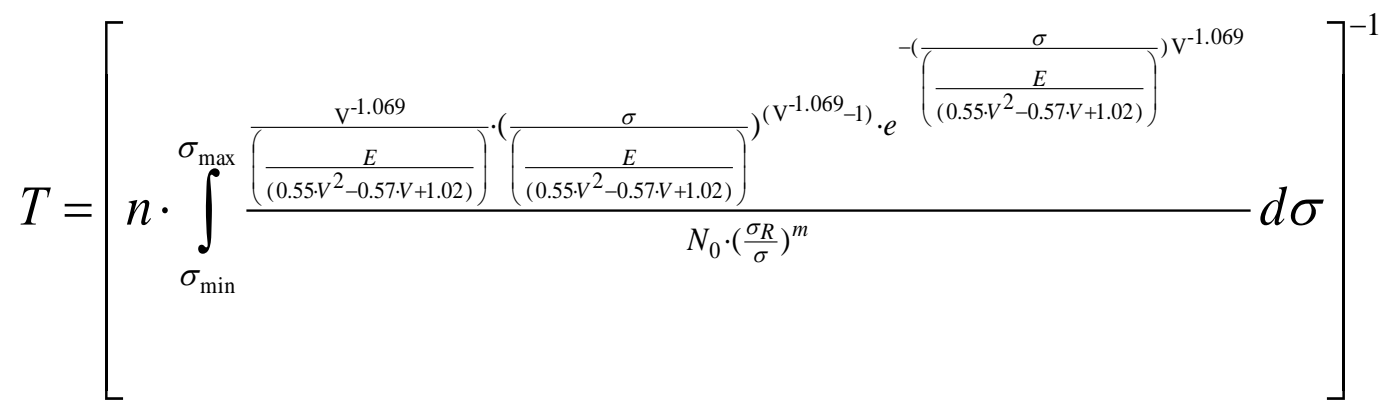

When calculating according to the given dependence, for example, the trailer frame 2PTS - 4 (Metodika uskorennykh prochnostnykh ispytaniy, 1968), based on the analysis of the performance test $\sigma_{\max }=171 \mathrm{Mpa}$, $\sigma_{\min }=30 \mathrm{Mpa}$, for the trailer frame material $N_{0}=2 \cdot 10^{6}$, the limit of liquidity $\sigma_{R}=\sigma_{-1}=220 M \Pi$, mathematical expectation $E=140$. According to recommendations (Popovych, \& Rybak, 2010; Chernovol, 1998), the expected number of cycles is assumed per unit of time $n=100$, the exponent $m=4$. After computing, the estimated performance of the trailer $\mathrm{T}=0.268 \cdot 10^{6}$, according to the results of experimental tests (Metodika uskorennykh prochnostnykh ispytaniy, 1968)T $=0.268 \cdot 10^{6}$. Therefore, the 
proposed model of preliminary assessment of performance is sufficiently correlated with the results of field research.

The ability of automobile trailer undercarriage materials to resist corrosive damages arising during the aggressive cargo transportation affects their reliability and durability. Based on the research results (Barna, \& Popovich, 2014; Barna, Popovich, \& Vovk, 2014), the best structural materials that provide cost reduction in the design of frame structures are developed for the manufacture of trailers.

\section{Conclusions}

The proposed analytical dependencies for preliminary assessment of the performance of automobile trailers undercarriages during their design and recommendations on choosing materials for their production will allow improving the reliability and efficiency of motor trailers to carry freight.

\section{Citation information}

Tson, O. (2016). Analytical evaluation of technical and operational indicators impact on the transportation technology by automobile trailers. Journal of Sustainable Development of Transport and Logistics, 1(1), 23-26. doi: 10.14254/jsdtl.2016.1-1.4.

\section{References}

Barna, R., \& Popovich, P. (2014). Influence of Operating Media on the Fatigue Fracture of Steels for Elements of Agricultural Machines. Materials Science, 50(3), 377-380.

Barna, R., Popovich, P., \& Vovk, R. (2014). The influence of Operating Environments on Fatigue Crack Grown Resistance of Steels for Elements of Agricultural Machines. Materials Science, 50(4), 225-228.

Chernovol, M., Hrankin, S., Malakhov, V., \& Cherkun, V. (1998). Reliability of agricultural machinery. Kyiv, Ukraine: Urozhay.

Dmytrychenko, S. (2003). Metody obespecheniya trebuemykh pokazateley metalloemkosti i dolgovechnosti mobil'nykh mashin [Methods of providing the required indicators of metal capacity and durability of mibile machinery]. Bulletin of mechanical engineering, 9. (in Russian).

Dmytrychenko, S. (2006). Opyt raschetov na prochnost', proektirovaniya i dovodki svarnykh metallokonstruktsiy mobil'nykh mashin [The calculations for strength, design and welded metal structures machines]. Tractors and agricultural machinery, 1. (in Russian).

Metodika uskorennykh prochnostnykh ispytaniy nesushchikh sistem mashin na poligone KubNIITiM [Methods of accelerated strength testing of machine bearing systems at the landfill Kuban NIITiM]. (1968). Novokubansk, USSR: Kuban NIITiM. (in Russian).

Popovych, P., \& Rybak, T. (2010). Kompleksnyi analiz nadiinosti nesuchykh system traktornykh prychepiv pry yikhnii ekspluatatsii [Comprehensive analysis of the reliability of tractor trailers in their operation]. Bulletin of KhNTUAE, 93, 411-414. (in Ukrainian).

Rybak, T. (2003). Poshukove konstruiuvannia na bazi optymizatsii resursu mobilnykh s/h mashyn [Search designing based on optimization of mobile agriculture machinery resources]. Ternopil, Ukraine: Zbruch Publishing. (in Ukrainian).

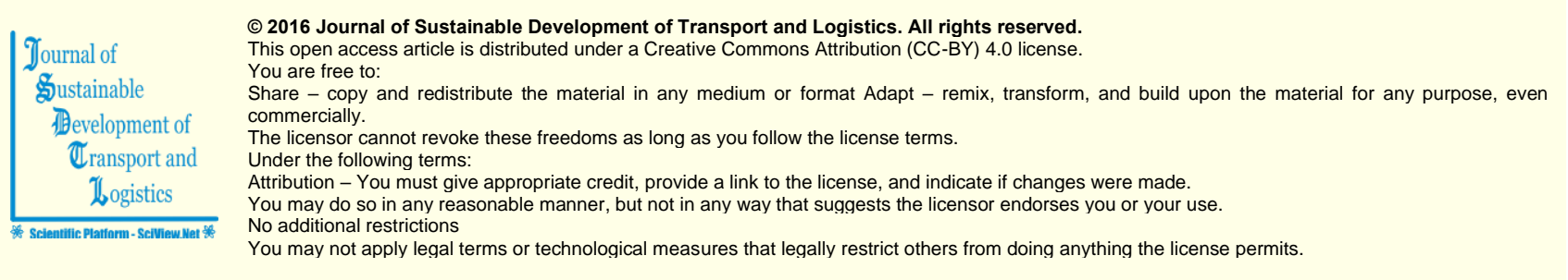

Journal of Sustainable Development of Transport and Logistics (ISSN: 2520-2979) is published by Scientific Publishing House "CSR", Poland, EU and Scientific Publishing House "SciView", Ukraine

Publishing with JSDTL ensures:

- Immediate, universal access to your article on publication

- High visibility and discoverability via the JSDTL website

- Rapid publication

- Guaranteed legacy preservation of your article

- Discounts and waivers for authors in developing regions

Submit your manuscript to a JSDTL at http://jsdtl.sciview.net/ or submit.jsdtl@sciview.net 